\title{
Psychological Empowerment to the Organizational Commitment and Turnover Intention of Social Worker
}

\author{
Jong-Soo Kang \\ Assistant Professor, Department of Social Welfare, \\ Kangwon National University, Samcheok-si, Gangwon-do, Korea
}

\begin{abstract}
Numerous studies have linked empowerment to employee's behaviors and attitudes. The purpose of this study was to examine the effects of empowerment on the organizational commitment and turnover intention of social worker in private social welfare organizations. For the research, empowerment was consisted of meaning, competence, self-determination and impact. This study was analyzed 342 social workers by survey. The results of this study were summarized as follows: Social Workers had correlation to empowerment on the organizational commitment $(+)$. Especially, meaning, self-determination and impact had a positive effect on the organizational commitment; Meaning, competence, and self-determination had a negative effect on the turnover intention. This study finally discussed theoretical implications for future study and practical implications for empowerment strategies on the results.
\end{abstract}

Keywords: empowerment, organizational commitment, turnover intention, social worker.

\section{INTRODUCTION}

In the highly competitive environment of service industries in which service providers must be fast and efficient in providing quality services, proactive service workers are essential [1][2]. Recent research has found that organizational empowerment is an important management tool used to motivate service employees to deliver service proactively to satisfy the changing needs of customers with responsiveness and flexibility [3].

Since the 1980s, public agencies and private firms increasingly have been relying on participative management techniques and employee empowerment practices aimed at sharing authority, information, and resources with frontline employees in order to improve performance [4],[5]. Effective participation is theorized to enhance retention by signaling to employees that their efforts are valued [6],[7]. Participation also encourages employee's self-identity and creates a sense of obligation to support organizational goals [8].

Empowerment refers to a situation in which a manager gives employees discretion to make day-to-day decisions about jobrelated activities [9]. Empowerment has been studied and used in practice in many other industries before it was found to be especially important in non-profit organization like social welfare. According to Kanter [10], work behaviors and attitudes are shaped by characteristics of the work environment, not intrapersonal traits. Work environments that provide access to support, information, resources and opportunities are

\footnotetext{
* Corresponding author. E-mail : jskang@kangwon.ac.kr Manuscript received Feb. 02, 2012 ; accepted Mar.20, 2012
}

considered to be empowering. Employees who are able to access these structures are empowered, active and productive within the organization, participate more actively in organizational activities and exhibit higher morale. In contrast, individuals in positions that limit access to empowerment structures become powerless feel less committed, have reduced job satisfaction and higher levels of organizational commitment.

The commitment of individuals to organizational goals has invoked wide interest from organizational experts and others. Organizational commitment is essentially about an individual's attitude and behavior towards an organization's goal. Shahnawaz and Juyal's [11] definition of organizational commitment as 'a force that binds an individual to a course of action that is of relevance to a particular goal', agrees with our view that organizational commitment is essentially about attitude and behavior towards shared goals of a group or organization. In the views of O'Reilly and Chatman [12], organizational commitment is '.. the psychological attachment felt by the person for the organization; it will reflect the degree to which the individual internalizes or adopts characteristics or perspectives of the organization'. Organizational commitment is the psychological bond that an employee has with an organization [13]. The impact of organizational commitment on individual performance and organizational effectiveness has drawn much attention from researchers [14]-[16] . Thus, what predicts organizational commitment has been an important research concern in the field of human resource development .

Also, job turnover has become such a pressing issue, because of the serious consequences that it creates for managers. In addition to creating turmoil and causing disruptions in service delivery, turnover imposes considerable costs on organizations: separation costs such as severance pay, as well as replacement 
costs, including the cost of hiring, screening, and training new employees. The average turnover costs for a full-time professional employee in the private sector have been estimated to be as high as 150 percent of the employee's annual compensation package [17].

Therefore, organizational commitment and turnover intention are one of the most frequently used variables for satisfaction and performance. Although there are diverse studies exploring psychological empowerment, organizational commitment, and turnover intention, little research has investigated the three topics simultaneously to reflect the dynamics in social welfare organizations. Thus, the purpose of this study is to examine the effects of empowerment on the organizational commitment and turnover intention of social worker in private social welfare organizations. This study provides a theoretical contribution by linking organizational commitment research with psychological empowerment and turnover intention research.

\section{LITERATURE REVIEW}

\subsection{Empowerment}

Empowerment as a concept is discussed both as structural empowerment and as psychological empowerment. Structural empowerment emphasizes social workers' access to an empowering structure and has been studied thoroughly by, for example, Laschinger et al. [18][19]; their work builds on the research of Kanter [10]. According to Kanter's model, high structural empowerment means the employee has greater access to support, resources, information and opportunities to learn and develop. Employees' formal and informal power, in turn, facilitates their access to the above-mentioned organizational structures. Informal power means power through others: alliances/social connections with peers, co-workers, subordinates, managers, mentors and others of significance in the work place; according to Kanter, this is essential to women [10].

The concept of psychological empowerment has been defined by Spreitzer as four cognitions [20],[21]. The four dimensions reflect a proactive, rather than passive orientation to one's work role [20][22]:

(1)Meaning is the value of a work goal or purpose, judged in relation to an individual's own ideals or standards.

(2) competence or self-efficacy is an individual's beliefs in his or her capability to perform activities with skill.

(3) self-determination is an individual's sense of having choice in initiating and regulating action's, the social workers' autonomy over work methods and processes.

(4) impact is the degree to which an individual can influence strategic, administrative, or operating outcomes at work.

Psychological empowerment is the social workers' subjective feelings about his/her specific work role and can't generalize across situations. According to research by Spreitzer and others, structural components at work are related to psychological empowerment, which in turn mediates effects of innovativeness [21], job strain and satisfaction [18],[19], and burn out [23].
From a psychological perspective, empowerment is a process leading to an internal cognitive state characterized by increased intrinsic task motivation [24] and enhanced feelings of selfefficacy [9]. Empirical findings show that empowerment can improve productivity, raise levels of employee satisfaction and organizational commitment, promote job involvement, and encourage innovativeness [20],[21],[25]. There is good reason to believe, therefore, that employees who feel empowered will be less likely to leave.

\subsection{Organization Commitment}

Mowday, Steers, and Porter defined organizational commitment as employees' identification with their firm and its goals [13]. Organizational commitment includes a strong belief and acceptance of organizational goals, a willingness to exert considerable effort on behalf of the company, and a strong desire to maintain membership in the firm [13],[26]. This bond between the individual and the organization develops out of a person's attitudes about the work and the firm. Mathieu and Zajac's meta-analysis summarized the results of more than 200 studies and reported that organizational commitment is correlated to several organizational variables, including job satisfaction, job scope, autonomy, and skill variety [27]. When employees have positive attitudes about their job, they are likely to have greater organizational commitment. Finally, depersonalization and personal no-accomplishment in employees can make employees feel alienated from the organization [28].

This study is based on Meyer and Allen's [14] three typologies of Affective, Continuance and Normative commitment. Affective typology was defined as 'the employee's emotional attachment to, identification with, and involvement in the organization'. Continuous attachment has to do with 'an awareness of the costs associated with leaving the organization', whereas Normative commitment was defined as a feeling of obligation to remain in the employment of the organization. Meyer and Allen's [14] classification of organizational commitment reflects our definition of organizational commitment as an emotional, moral and rational phenomenon. This study focuses on affective and continuance organizational commitment, which is specifically defined as 'the employee's emotional attachment to, identification with, and involvement in the organization'. Employees with a strong affective and continuance commitment tend to continue employment with the organization.

Several researchers suggest that empowered employees have a higher level of organizational commitment, as empowered employees tend to be highly concentrated, self-motivated and resilient [10],[18],[29]. Empowering conditions, such as opportunities for decision autonomy, challenge, and responsibility make employees appreciate what they have. In turn, such appreciation results in feelings of meaning, competence, self-determination, and impact [30]. Consequently, they are likely to reciprocate by being more committed to an organization [31],[32]. Thus, it is likely that the more employees are empowered, the more highly they are committed to their organization.

\subsection{Turnover Intention}


Turnover intentions pertain to thoughts of voluntarily leaving the organization. A literature review by Bluedorn [33] cites 23 studies that report finding significant positive relationships between leaving intentions and actual leaving behavior. Workforce stability is a powerful competitive strategy that is expected to become increasingly important in the foreseeable future. How is workforce stability a competitive edge? It builds a long-term and consistent relationship between employee and organization.

There is extended evidence suggesting that dissatisfaction with the work environment is an important precursor of an employee's decision to leave the organization or profession. In particular, characteristics of the direct working environment have been found to predict job satisfaction [34]. Moreover, job satisfaction has been related strongly to turnover intention.

Employees create efficiency and effectiveness by nurturing stable organizational relationships; they will then stay long enough to become familiar with their customers, suppliers and colleagues, and they will work to become more stable. Empowered social worker would be highly self-efficacy. Selfefficacy beliefs influence cognitive and behavioral responses to uncertainty and stress. People with strong self-efficacious beliefs focus their attention on problem-solving solutions, whereas those doubting their abilities become preoccupied with possible failure scenarios [35].

Based on these findings and theoretical background, it was expected that empowerment and organizational commitment also would be an important aspect of social workers' consideration to leave the social welfare organization or industry.

\section{RESEARCH METHOD}

\subsection{Research Questions}

Based on the limited existing research conducted on social workers and few studies examining the variables proposed for this study, the following research questions were proposed;

Question 1) What is the level of psychological empowerment, organizational commitment, and turnover intention perceived by social worker?

Question 2) What are the relationships among psychological empowerment, organizational commitment, and turnover intention?

\subsection{Data Collection}

A convenience sample of 342 social workers participated in this study. Questionnaires were used for the analysis.

\subsection{Measurement}

3.2.1 Empowerment: The 12-item Psychological Empowerment Scale developed by Spreitzer [20] measuring the four components of psychological empowerment, meaningful work, competence, self-determination and impact, in a work context was used. Each subscale has three items. Response alternatives are five grade ranging from one (strongly disagree) to five (strongly agree). Total scale and sub-scale scores are averaged to form indexes that range from 1-5. Spreitzer [20] established evidence of convergent and divergent validity of the four dimensions and reported acceptable reliability levels (range: 0.62-0.72). Alpha reliability in this study was .91.

3.2.2 Organization Commitment: Of the three characteristics of organizational commitment, we used affective and normative organizational commitment (6-items) [14]. A sample item was, 'I would be very happy to spend the rest of my career with this organization'. In this study, the reliability was .94.

3.2.3 Turnover Intention: We measured turnover intention with three items using a 5-point Likert scale, ranging from 1 (totally disagree) to 5 (totally agree). The three items were: leaving the organization as a result of better opportunities elsewhere, a deliberate search for vacancies in other organizations and the wish to work in another organization. The three items exhibited internal consistency reliability (Cronbach's alpha) of .87 in our study. Data coding was done in such a way that a higher score indicated a higher intention to leave.

\subsection{Data Analysis}

All the descriptions and analyses were carried out by using the SPSS program (ver. 14.0k). Reliability analyses (Cronbach's alpha) were conducted for the measures of all the major study variables. Descriptive statistical analyses, pearson's correlation analyses, and hierarchical multipleregression were used to answer the research questions. Multicollinearity among the predictor variables was assessed using variance inflation factors (VIF).

\section{RESULRS OF ANALISES}

\subsection{Demographic characteristics}

Table 1 shows the demographic characteristics of the respondents. The demographic variables included: (a) gender, (b) age, (c) marital status, (d) education level, (e) certificate of qualification. Among the 342 respondents, 102 were male (29.2\%), and 240 were female (70.2\%). $34.2 \%$ of the participants' ages were between 30 and $39 ; 31.62 \%$ of the participants' ages were under 29; and 45 participants (13.2\%) were over 50 years old. In terms of educational level, $56.7 \%$ of the respondents graduated from four-year university courses. $53.5 \%$ of the participants were married.

Table 1. Demographic characteristics of the respondents

\begin{tabular}{|c|c|c|c|c|}
\hline & & & & $(n=342)$ \\
\hline & & $\mathrm{n}$ & $\%$ & Missing \\
\hline \multirow{2}{*}{ Gender } & Male & 102 & 29.8 & \multirow{2}{*}{-} \\
\hline & Female & 240 & 70.2 & \\
\hline \multirow{4}{*}{$\begin{array}{l}\text { Age } \\
\text { (year) }\end{array}$} & $20 \sim 29$ & 108 & 31.6 & \multirow{4}{*}{ 1(.3) } \\
\hline & $30 \sim 39$ & 117 & 34.2 & \\
\hline & $40 \sim 49$ & 71 & 20.8 & \\
\hline & $50 \leq$ & 45 & 13.2 & \\
\hline
\end{tabular}




\begin{tabular}{lllll}
\hline \multirow{2}{*}{ Marital status } & Not married & 159 & 46.5 & - \\
\cline { 2 - 4 } & Married & 183 & 53.5 & \\
\hline \multirow{2}{*}{ Education } & College & 84 & 24.6 & $2(.6)$ \\
\cline { 2 - 4 } & Bachelors & 194 & 56.7 & \\
\cline { 2 - 4 } & $\begin{array}{l}\text { Graduate } \\
\text { course }\end{array}$ & 62 & 18.1 & $2(.6)$ \\
\hline $\begin{array}{l}\text { Certificate of } \\
\text { qualification }\end{array}$ & 1 & 136 & 39.8 & \\
\cline { 2 - 4 } & 2.3 & 204 & 59.7 & \\
\hline
\end{tabular}

\subsection{Descriptive statistics}

Table 2 shows the means values and SDs of the major variables in this study. The level of the overall empowerment and organizational commitment had a higher than medium(mean=3.83, 3.59). Especially, meaning was very high than any other sub-scale of empowerment(mean=4.25). But, the level of turnover intention had a lower than medium(mean=2.75).

Table 2. Descriptive Statistics of the major variable

\begin{tabular}{lccccc}
\hline Variable & Mean \pm SD & Min & Max & $\begin{array}{l}\text { Skew } \\
\text { ness }\end{array}$ & $\begin{array}{l}\text { Kurt } \\
\text { osis }\end{array}$ \\
\hline Empowerment & $3.83 \pm .62$ & 2.00 & 5.00 & .06 & -.59 \\
\hline meaning & $4.25 \pm .75$ & 1.00 & 5.00 & .85 & .55 \\
\hline competence & $3.87 \pm .73$ & 1.67 & 5.00 & .05 & -.56 \\
\hline $\begin{array}{l}\text { self- } \\
\text { determination }\end{array}$ & $3.70 \pm .77$ & 1.00 & 5.00 & -.26 & .26 \\
\hline impact & $3.49 \pm .91$ & 1.33 & 5.00 & -.06 & .68 \\
\hline $\begin{array}{l}\text { Organizational } \\
\text { Commitment }\end{array}$ & $3.59 \pm .90$ & 1.00 & 5.00 & -.39 & -.16 \\
\hline $\begin{array}{l}\text { Turnover } \\
\text { Intention }\end{array}$ & $2.75 \pm 1.07$ & 1.00 & 5.00 & .06 & -.70 \\
\hline
\end{tabular}

\subsection{Correlation Analysis}

Empowerment was positively related to the organizational commitment( $\mathrm{r}=.57, \mathrm{p}=.000)$ and turnover intention( $\mathrm{r}=-.32$, $\mathrm{p}=.000$ ). Furthermore, all factors of empowerment showed statistically significant positive correlation with organizational commitment: meaning( $\mathrm{r}=.45, \mathrm{p}=.000)$, competence $(\mathrm{r}=.27$, $\mathrm{p}=.000)$, self-determination $(\mathrm{r}=.45, \mathrm{p}=.000), \quad \operatorname{impact}(\mathrm{r}=.57$, $\mathrm{p}=.000$ ). Also, organizational commitment was significantly negatively correlated with the turnover intention( $\mathrm{r}=-.61$, $\mathrm{p}=.000$ ), as indicated in Table 3 .

Table 3. Pearson's correlation Matrix

\begin{tabular}{|c|c|c|c|c|c|c|}
\hline Variable & (1) & (2) & (3) & (4) & (5) & (6) \\
\hline (1) Empowerment & 1 & & & & & \\
\hline (2) meaning & $.72^{* * *}$ & 1 & & & & \\
\hline (3) competence & $.76^{* * *}$ & $.46^{* * *}$ & 1 & & & \\
\hline $\begin{array}{l}\text { (4) self- } \\
\text { determination }\end{array}$ & $.82^{* * * *}$ & $.40^{* * *}$ & $.57^{* * *}$ & 1 & & \\
\hline (5) impact & $.81^{* * *}$ & $.43^{* * *}$ & $.41^{* * *}$ & $.61^{* * *}$ & 1 & \\
\hline $\begin{array}{c}\text { (6) Organizational } \\
\text { Commitment }\end{array}$ & $.57^{* * *}$ & $.45^{* * *}$ & $.27^{* * *}$ & $.45^{* * *}$ & $.57^{* * *}$ & 1 \\
\hline $\begin{array}{l}\text { (7) Turnover } \\
\text { Intention }\end{array}$ & $\begin{array}{l}- \\
.32^{* * *}\end{array}$ & $\begin{array}{l}- \\
.31^{* * *}\end{array}$ & $-.12^{*}$ & $\begin{array}{l}- \\
.26^{* * *}\end{array}$ & $\begin{array}{l}- \\
.31^{* * *}\end{array}$ & $\begin{array}{l}- \\
.61^{* * *}\end{array}$ \\
\hline
\end{tabular}

\subsection{Hierarchical multiple regression analysis}

To test the research questions of this study, hierarchical multiple regression analysis was used. Table 4 illustrates the results of hierarchical multiple regression of psychological empowerment and organizational commitment. In step 1, to control demographic variables, gender, age, marital status, education, and certificate of qualification were entered. These control variables accounted for $10 \%$ of the variance in organizational commitment. Age and educational level were found to be significant. That is, the higher an employee's education level, the lower his or her organizational commitment. In contrast, the higher an employee's age, the higher his or her organizational commitment. In step 2, the main effects of the four dimensions of psychological empowerment explained an additional $41 \%$ of the variance in organizational commitment. Except for competency, three dimensions of psychological empowerment turned out to be significant; meaning $(\beta=4.97)$, self-determination $(\beta=3.00)$, impact $(\beta=5.69)$. Impact indicated a stronger effect size than meaning and self-determination.

Table 4. Regression Results for Organizational Commitment

\begin{tabular}{|c|c|c|c|c|c|c|c|}
\hline \multirow{2}{*}{\multicolumn{3}{|c|}{ Independent Variable }} & \multicolumn{2}{|c|}{ Model 1} & \multicolumn{3}{|c|}{ Model 2} \\
\hline & & & $\beta$ & VIF & $\beta$ & $\mathrm{t}$ & VIF \\
\hline \multirow{6}{*}{ Demo } & (Constant) & & $8.59^{* * *}$ & & & $1.38^{* * *}$ & \\
\hline & Gender(M) & .01 & .26 & 1.05 & .01 & .32 & 1.08 \\
\hline & Age & .26 & $4.10^{* * *}$ & 1.56 & .14 & $2.73^{* *}$ & 1.64 \\
\hline & $\begin{array}{l}\text { Marital } \\
\text { Status(N) }\end{array}$ & .04 & .68 & 1.56 & .01 & .25 & 1.57 \\
\hline & Certificate (1) & .03 & .63 & 1.18 & .04 & .92 & 1.19 \\
\hline & Education & -.11 & $-2.10^{*}$ & 1.11 & $\begin{array}{l}- \\
.05\end{array}$ & -1.17 & 1.12 \\
\hline \multirow{4}{*}{ Emp } & Meaning & & & & .25 & $4.97^{* * *}$ & 1.45 \\
\hline & Competence & & & & .09 & .1 .78 & 1.67 \\
\hline & $\begin{array}{l}\text { Self- } \\
\text { determination }\end{array}$ & & & & .18 & $3.00^{* *}$ & 2.02 \\
\hline & Impact & & & & .33 & $5.69^{* * *}$ & 1.87 \\
\hline \multicolumn{2}{|c|}{$\mathrm{R}^{2}$ (Adj. $\mathrm{R}^{2}$ ) } & \multicolumn{3}{|c|}{$.10(.09)$} & \multicolumn{3}{|c|}{$.41(.39)$} \\
\hline \multicolumn{3}{|c|}{$\triangle R^{2}$} & \multicolumn{2}{|l|}{-} & \multicolumn{3}{|c|}{.30} \\
\hline \multicolumn{3}{|c|}{ Durbin-Watson } & \multicolumn{2}{|l|}{-} & \multicolumn{3}{|c|}{1.88} \\
\hline \multicolumn{3}{|c|}{$\mathrm{F}$} & \multicolumn{2}{|l|}{$8.10^{* * *}$} & \multicolumn{3}{|c|}{$25.57^{* * *}$} \\
\hline
\end{tabular}

Note1: Gender $0=$ Female, Marital status $0=$ Married, Certificate $0=2 \cdot 3$

Note2: Demo= Demographic characteristics, Emp= Empowerment

Table 5 illustrates the results of hierarchical multiple regression of psychological empowerment and turnover intention. In step 1, control demographic variables accounted for $12 \%$ of the variance in turnover intention. Age and marital status (Not Married) were found to be significant. In step 2, the main effects of the four dimensions of psychological empowerment explained an additional $22 \%$ of the variance in turnover intention. Except for impact, three dimensions of psychological empowerment turned out to be significant: meaning $(\beta=-3.77)$, competence $(\beta=-2.63)$. self- 
Table 5. Regression Results for Turnover Intention

\begin{tabular}{|c|c|c|c|c|c|c|c|}
\hline \multirow{2}{*}{\multicolumn{2}{|c|}{ Independent Variable }} & & \multicolumn{2}{|c|}{ Model 1} & \multicolumn{3}{|c|}{ Model 2} \\
\hline & & & $\mathrm{t}$ & VIF & $\beta$ & $\mathrm{t}$ & VIF \\
\hline \multirow{6}{*}{ Demo } & (Constant) & & $7.91^{* * *}$ & & & $9.63^{* * *}$ & \\
\hline & Gender(M) & $\begin{array}{l}- \\
.08\end{array}$ & -1.59 & 1.05 & $\begin{array}{l}- \\
.08\end{array}$ & -1.72 & 1.08 \\
\hline & Age & $\begin{array}{l}- \\
.24\end{array}$ & $-3.79^{* * * *}$ & 1.56 & $\begin{array}{l}- \\
.19\end{array}$ & $-3.13^{* *}$ & 1.64 \\
\hline & $\begin{array}{l}\text { Marital } \\
\text { Status(N) }\end{array}$ & $\begin{array}{l}- \\
.13\end{array}$ & $-2.08^{*}$ & 1.55 & $\begin{array}{l}- \\
.12\end{array}$ & $-2.02^{*}$ & 1.57 \\
\hline & Certificate(1) & .00 & .05 & 1.18 & $\begin{array}{l}- \\
.01\end{array}$ & -.14 & 1.19 \\
\hline & Education & .08 & 1.53 & 1.11 & .05 & .99 & 1.12 \\
\hline \multirow{4}{*}{ Emp } & Meaning & & & & $\begin{array}{l}- \\
.22\end{array}$ & $-3.77^{* * *}$ & 1.45 \\
\hline & Competence & & & & $\begin{array}{l}- \\
.16\end{array}$ & $-2.63^{* * *}$ & 1.67 \\
\hline & $\begin{array}{l}\text { Self- } \\
\text { determination }\end{array}$ & & & & $\begin{array}{l}- \\
.19\end{array}$ & $-2.76^{* *}$ & 2.01 \\
\hline & Impact & & & & $\begin{array}{l}- \\
.08\end{array}$ & -1.32 & 1.87 \\
\hline \multicolumn{2}{|r|}{$\mathrm{R}^{2}\left(\right.$ Adj. $\left.\mathrm{R}^{2}\right)$} & \multicolumn{3}{|c|}{ (.10) } & \multicolumn{3}{|c|}{$.22(.20)$} \\
\hline
\end{tabular}

\begin{tabular}{ccc}
$\mathrm{R}^{2}\left(\right.$ Adj. $\left.\mathrm{R}^{2}\right)$ & $.12(.10)$ & $.22(.20)$ \\
\hline$\Delta \mathrm{R}^{2}$ & - & .10 \\
\hline Durbin-Watson & - & 1.99 \\
\hline $\mathrm{F}$ & $9.11^{* * *}$ & $10.63^{* * *}$ \\
\hline
\end{tabular}

${ }^{*} \mathrm{p}<.05,{ }^{* *} \mathrm{p}<.01,{ }^{* * *} \mathrm{p}<.001$

Note1: Gender $0=$ Female, Marital status $0=$ Married, Certificate $0=2 \cdot 3$

Note2: Demo= Demographic characteristics, Emp= Empowerment

\section{CONCLUSION}

The job attitude of social worker is related to their job intention in the service environment. The results of this study demonstrate a positive correlation among social workers' empowerment, their organizational commitment and turnover intention. This study found that psychological empowerment positively and significantly affected the level of social workers' organizational commitment and turnover intention. Detailed findings are discussed below.

Social worker exhibited higher organizational commitment and lower turnover intention when they had higher psychological empowerment. Overall $41 \%$ and $21 \%$ of the variance in organizational commitment were explained by the above-mentioned factors. Among the four dimensions of psychological empowerment, meaning, self-determination and impact showed positive and significant relationships with organizational commitment. This result was consistent with the findings in previous research studies [19][31]. The results of the current study showed that meaning had the strongest effect on commitment. Social worker perceived higher organizational commitment when the task goal or purpose is met with individual value. This study also found that while the regression coefficient of competence was non-significant. And social workers demonstrated the lower turnover intention when they perceived a higher psychological empowerment.
With improved empowerment, a social worker may contribute more to the organization without lobbying for extra compensation. Improving empowerment can help reduce turnover intention and encourage voluntary contributions to improve net organizational performance. This study identifies a helpful connection between social workers' job attitudes and their turnover intention. Therefore, manager or supervisors should establish environments preferable to increasing social

64 workers' empowerment for improving organizational commitment and reducing turnover intention because empowerment is not generalize an enduring personality trait across situations, but rather a set of cognitions shaped and changed by a work environment [24][36]. By providing training and development programs for managers to adopt new roles as coaches, mentors and facilitators, the level of employees' psychological empowerment can be increased.

Despite its contributions, this study has some limitations. First, our study relied on self-reported data, and thus is subject to common method variance [37]. Second, as we used a crosssectional design, we could not arrive at a definitive conclusion about causality. Although we built upon previous studies and argued for the causal precedence of empowerment practice, there was a possibility of reverse causation because we measured only perceived empowerment practices. A third potential limitation is that the sample in this study was taken from a single industrial firm, thereby limiting the generalization of the findings. .

\section{REFERENCES}

[1] D. E. Bowen and E. E. Lawler, "The empowerment of service workers: what, why, how, and when?”, Sloan Management Review, vol. 33, no. 3, 1992, pp. 9-31.

[2] M. Fulford and C. Enz, "The impact of empowerment on service employees”, Journal of Managerial Issues, vol. 7, no. 2, 1995, pp. 161-175.

[3] M. Jo. Bitner, B. H. Booms, and M. S. Tetreault, "The Service Encounter: Diagnosing Favorable and unfavorable Incidents”, Journal of Marketing, vol.54, 1990, pp. 71-84.

[4] P. S. Kim, "Modernizing the Korean civil service: Policy alternatives for democratization", The Asian Journal of Public administration, vol.14, no. 1, 2002, pp.63-78.

[5] D. E. Bowen and E. E. Lawler, E.E. (1995). "Empowering service employees," Sloan Management Review, vol. 36, no. 4, 1995, pp. 73-84.

[6] F. M. Hudson, The handbook of coaching: A comprehensive resource guide for managers, consultants, and human resource professionals, CA: Jossey Bass, San Francisco, 1999.

[7] J. B. Blau and R. D. Alba, "Empowering nets of participation”, Administrative Science Quarterly, vol. 27, 1982, pp. 363-379.

[8] D. A. Harrison, D. A. Newman, and P. L. Roth, "How important are job attitudes? Meta-analytic comparisons of integrative behavioral outcomes and time sequences”, Academy of Management Journal, vol. 49, 2006, pp. 305325. 
[9] J. A. Conger and R. N. Kanungo, "The empowerment process: Integrating theory and practice”, Academy of Management Review, vol. 13, no. 3, 1988, pp. 471-482.

[10] R. Kanter, Men and women of the corporation, Basic Books, New York, 1977.

[11] M. G. Shahnawaz and R. C. Juyal, "Human resource management practices and organizational commitment in different organizations", Journal of the Indian Academy of Applied Psychology, vol. 32, no. 3, 2006, pp. 171-178.

[12] C. A. O'Reilly and J. Chatman, “Organizational commitment and psychological attachment: the effects of compliance, identification and internalization on prosocial behavior”, Journal of Applied Psychology, vol. 71, 1986. pp. 492-499.

[13] R. Mowday, R. Steers, and L. Porter, Employeeorganization linkages: the psychology of commitment, absenteeism, and turnover, NY: Academic Press, New York, 1982.

[14] N. J. Allen and J. P. Meyer, “Affective, continuance, and normative commitment to the organization: An examination of construct validity", Journal of Vocational Behavior, vol. 49, no. 3, 1996, pp.252-276.

[15] K. Beck, and C. Wilson. Development of affective organizational commitment: A crosssequential examination of change with tenure. Journal of Vocational Behavior. Vol. 56, no. 1, 2000, pp. 114-136.

[16] R. Mowday, Reflections on the study and relevance of organizational commitment. Human Resource Management Review, vol. 8, no. 4, 1998, pp. 387-401.

[17] L. A. Schlesinger and J. L. Heskett, "The Service-Driven Company”, Harvard Business Review, vol. 69, no. 5, 1991, pp. 71-81.

[18] H. K. S. Laschinger, J. Finegan, and S. Judith, "The Impact of Workplace Empowerment, Organizational Trust on Staff Nurses' Work Satisfaction and Organizational Commitment", Health Care Management Review, Frederick, vol. 26, no. 3, 2001, pp. 7-23.

[19] H. K. S. Laschinger, J. Finegan, J. Shamian, and P. Wilk, "A longitudinal analysis of the impact of workplace empowerment on work satisfaction", Journal of Organizational Behavior, vol. 25, 2004, pp. 527-545.

[20] G. M. Spreitzer, "Psychological empowerment in the workplace: Dimensions, measurement, and validation", Academy of Management Journal, vol. 38, no. 4, 1995, pp. $1442-1465$.

[21] G. M. Spreitzer, "Social structural characteristics of psychological empowerment”, The Academy of Management Journal, vol. 39, no. 2, 1996, pp. 483-504.

[22] G. M. Spreitzer, M. A. Kizilos, and S. W. Nason, A dimensional analysis of the relationship between psychological empowerment and effectiveness, satisfaction, and strain. Journal of Management, vol. 23, no. 5, 1997, pp. 679-704.

[23] J. Hochwalder and B. A. Bergsten, “A psychometric assessment of a Swedish translation of Spreitzer's empowerment scale", Scandinavian Journal of Psychology, vol. 46, no.6, 2005, pp. 521-529.

[24] K. W. Thomas and B. A. Velthouse, "Cognitive elements of empowerment: An interpretive model of intrinsic task motivation”, Academy of Management Review, vol. 15, no. 4, 1990, pp. 666-681.

[25] B. L. Kirkman and B. Rosen, "Beyond self-management: Antecedents and consequences of team empowerment”, Academy of Management Journal, vol. 42, 1990, pp. 5875.

[26] P. E. Spector, "Measurement of Human Service Staff Satisfaction: Development of the Job Satisfaction Survey”, American Journal of Community Psychology, vol. 13, no. 6, 1985, pp. 693-713.

[27] J. E. Mathieu and D. Zajac, “A review and meta-analysis of the antecedents, correlates, and consequences of organizational commitment”, Psychology Bulletin, vol. 108, no. 2, 1990, pp. 171-194.

[28] R. P. Tett and J.P. Meyer, “Job Satisfaction, Organizational Commitment, Turnover Intention, and Turnover: Path Analyses Based on Meta-Analytic Findings”, Personnel Psychology, vo. 46, no. 2, 1993, pp.259-293.

[29] M. L. Kraimer, S. E. Seibert, and R. C. Linden, Psychological empowerment as a multidimensional construct: A test of construct validity. Educational and Psychological Measurement, vol. 59, no. 1, 1999, pp. 127-42.

[30] R. C. Linden, S. J. Wayne, and R. T. Sparrow, An examination of the mediating role of psychological empowerment on the relations between the job, interpersonal relationships, and work outcomes. Journal of Applied Psychology, vol. 85, no. 3, 2000, pp. 407-16.

[31] B. J. Avolio, W. Zhu, W. Koh, and P. Bhatia, "Transformational leadership and organizational commitment: Mediating role of Psychological empowerment and moderating role of structural distance”, Journal of Organizational Behavior, vol. 25, no. 8, 2004, pp. 951-968.

[32] R. Eisenberger, P. Fasolo, and V. Davis-LaMastro, Perceived organizational support and employee diligence, commitment, and innovation. Journal of Applied Psychology, vol. 75, no. 1, 1990, pp. 1-59.

[33] A. C. Bluedorn, "A unified model of turnover form organizations”, Human Relation, vol. 35, 1982, pp.135153.

[34] R. W. Griffeth, W. H. Peter, and S. Gaertner, “A MetaAnalysis of Antecedents and Correlates of Employee Turnover: Update, Moderator Tests, and Research Implication for the Next Millennium”, Journal of Management, vol. 26, no. 3, 2000, pp. 463-488.

[35] R. S. Lazarus, "From psychological stress to the emotions: a history of changing outlooks", Annual Review of Psychology, vol. 44, 1993, pp. 1-21.

[36] L. Y. Sun, S. Aryee, and K. S. Law, High-performance human resource practices, citizenship behavior, and organizational performance: A relational perspective. Academy of Management Journal, vol. 50, no. 3, 2007, pp. 558-577.

[37] N. P. Podsakoff, A. L. Jeffrey, and M. A. Le Pine, "Differential Challenge Stressor-Hindrance Stressor Relationships with Job Attitudes, Turnover Intentions, Turnover, and Withdrawal Behavior: A Meta-Analysis”, 
Journal of Applied Psychology, vol. 92, no. 2, 2007, pp. 438-454.

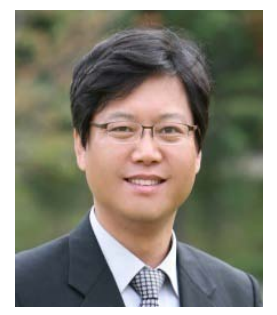

\section{Professor, Jong-Soo Kang}

He received the Ph.D. in social welfare from Pusan National University, Korea in 2007, He has been working in Kangwon National University as a professor since 2008. His main research interests include social welfare policy and administration. 